\title{
Baseline survey: Summary report of district DG Khan
}

Pakistan Initiative for Mothers and Newborns (PAIMAN)

Follow this and additional works at: https://knowledgecommons.popcouncil.org/departments_sbsr-rh

Part of the Family, Life Course, and Society Commons, and the Maternal and Child Health Commons How does access to this work benefit you? Let us know!

\section{Recommended Citation}

Pakistan Initiative for Mothers and Newborns (PAIMAN). 2006. "Baseline survey: Summary report of district DG Khan." Islamabad: Population Council. 


\section{Baseline Survey Summary Report}

\section{District D G Khan}

\section{Introduction}

This summary report presents some of the key findings of a 2005 baseline household survey in Dera Ghazi Khan (DG Khan) district, one of the ten districts in Pakistan that are the focus of the PAIMAN project. The Pakistan Initiative for Mothers and Newborns (PAIMAN) is a five-year project funded by the United States Agency for International Development (USAID). PAIMAN is committed to assist the Government of Pakistan in its implementation of the full spectrum of interventions necessary to address maternal and neonatal health (MNH) issues. The PAIMAN district survey results are presented individually; the districts are: Rawalpindi, Jhelum, Khanewal and DG Khan in Punjab; Dadu and Sukkur in Sindh; Jaffarabad and Lasbela in Balochistan; and Upper Dir and Buner in North West Frontier Province.

PAIMAN has developed a monitoring and evaluation plan to ensure that the success of the project was properly ascertained, and that the appropriate lessons learned. PAIMAN conducted the baseline household survey in the ten districts in order to understand local $\mathrm{MNH}$ perceptions and practices. The study population included all currently married women of reproductive age (15-49 years) living in all urban and rural areas of the district. The sampling design was a stratified, systematic sample of households.

In DG Khan, 878 women were interviewed for the study, of whom 754 (86 percent) were rural. Thirty percent of respondents were literate. On average, respondents had borne 4.4 children, of whom 3.9 were still living. 


\section{Knowledge,}

Attitude

\section{and Behavior}

Figure 1: Percentage of married women in DG Khan who know at least 3 danger signs

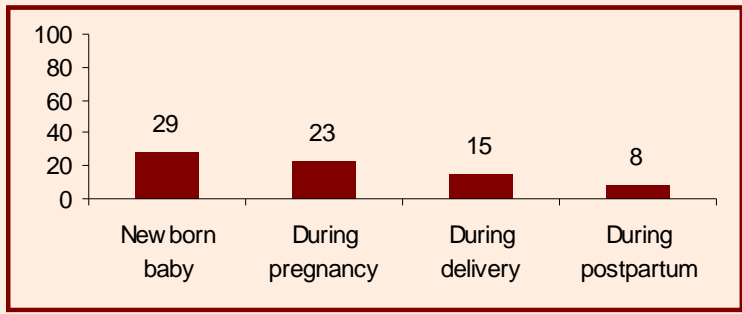

Figure 2: Percentage of married women in DG Khan who received antenatal care, TT injections and iron folate during their last pregnancy

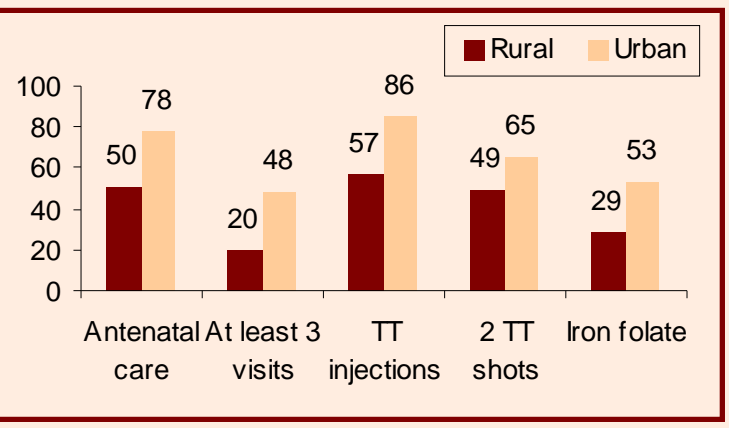

Figure 3: Percentage of married women in DG Khan who receive antenatal services during their antenatal visits, by type of services

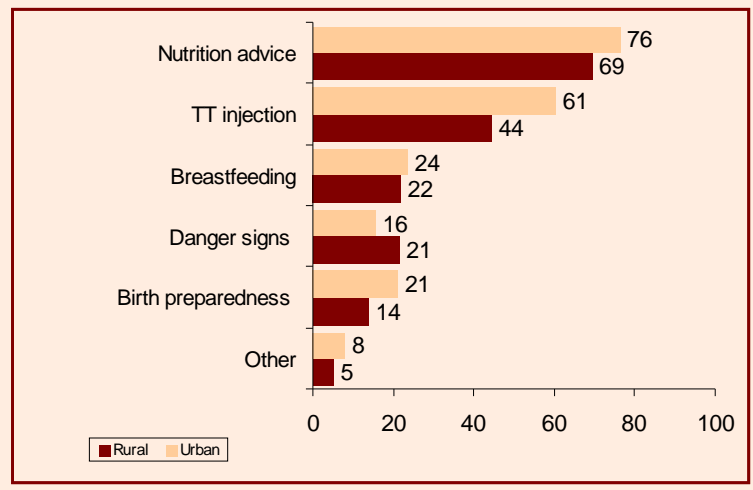

\section{Few Women Know Danger Signs Well}

\section{Knowledge of danger signs}

Only a small proportion of married women recognize three or more danger signs during pregnancy, during delivery, in the postpartum period, and in newborns (figure 1).

\section{Source of information regarding danger signs}

* Most receive information from their in-laws, family members and friends.

* About 12 percent indicate that they receive information primarily from television.

* Only 4 percent in rural areas indicate that Lady Health Workers are their source.

* District/Tehsil Headquarter Hospitals are also a source for about 3 percent rural and 2 percent urban.

\section{Most Women Receive Antenatal Care}

* Over 80 percent consider it necessary for women to receive antenatal check-ups.

* More than one-third believe that an antenatal check-up should occur in the first three months of pregnancy.

* For their last pregnancy, half of rural pregnant women and 78 percent urban had an antenatal check-up but only 20 percent rural and 48 percent urban had three or more, the national standard (figure 2).

* Over half rural areas and 86 percent urban areas had TT injections during their last pregnancy, while 49 percent rural and 65 percent urban had two TT shots.

* About one-third took iron folate tablets during their last pregnancy.

\section{Components of antenatal check-up}

Figure 3 suggests that, while a majority of women are advised on nutrition and tetanus immunization, most women are not advised about preparing for emergencies.

\section{Many Women Prepare for Childbirth; Most Deliver at Home With an Unskilled Attendant}

\section{Preparedness for childbirth}

Figure 4 shows that a large percent of urban women appear to have made appropriate arrangements for the delivery, but few rural women have done so, especially for emergencies.

\section{Place of delivery and services}

* More than three-quarters agree that delivery services should be obtained from skilled birth attendants.

* D ata obtained on births that occurred during the last three years show that 77 percent of rural and 43 percent of urban women delivered their babies at home (figure 5).

* Twenty-eight percent of deliveries are conducted by a skilled birth attendant.

\section{Delivery characteristics}

From figure 6, more than 87 percent of rural and 67 percent of urban respondents 
indicate they had a normal vaginal delivery. The proportion of Caesarean sections in urban DG Khan is 10 percent, within WHO guidelines.

\section{Complications During Pregnancy and Childbirth are Common}

- In rural areas, almost three out of five pregnant women indicate they experienced a complication during their last pregnancy, while two out of five in urban areas made the same claim. Severe headache, blurring of vision and severe abdominal pain are the complications most reported.

- More than one-thirdof women report experiencing at least one complication during delivery. About 20 percent in rural areas report experiencing excruciating pain during their last pregnancy, whereas only 8 percent urban report the same. Prolonged labor, premature rupture of membranes and excessive bleeding are among other reported complications.

* For many of these complications, women receive no care or inappropriate care.

\section{Postpartum and Newborn Care Need Attention}

\section{Postpartum check-up}

* More than 49 percent in rural areas and 31 percent urban feel that postnatal care is not necessary. Married women are often not aware of the complications that can arise following birth, and may ignore the symptoms.

* For those who delivered their last baby at home, 84 percent did not receive any postnatal check-ups.

* Among those who go for postnatal care, 22 percent go within 24 hours after childbirth. childbirth.

\section{Immediate care of newborn}

* While more than 16 percent of the mothers report that their newborns were with them immediately following delivery, a large percent indicate that their newborns are placed on either a piece of cloth (rural: 48 percent) or on a mattress (urban: 30 percent).

* About 14 percent indicate that their newborns are placed on the floor immediately after delivery.

- About 39 percent of newborns are given a bath within 60 minutes of birth; more than 42 percent are bathed after the recommended six hours.

\section{Colostrum and breastfeeding}

About 98 percent of urban and rural mothers indicate that they did breastfeed their child. In rural areas, 61 percent state that they give colostrum to their babies; 77 percent do so in urban areas. Of those who gave colostrum to their newborns, 11 percent gave it within the first hour after birth. More than three-quarters in urban and two-thirds in rural areas report giving the baby something other than breast milk within the first three days.

\section{Neonatal care}

* For the last live child born, 18 percent were examined by a skilled provider soon after birth. Problems noticed immediately after birth include difficult breathing and weak or no cry. Jaundice is the most commonly noted complication in newborns within the first seven days after birth.

* The most common choices for treatments for newborns in rural and urban areas are private hospitals/clinics.

* No external treatment was sought for reported symptoms in 19 percent of rural cases and one-third urban.

\section{Clean Delivery Practices}

Respondents who delivered their last child at home report the following delivery practices:

* TBA did not wash her hands with soap for 19 percent of rural and 11 percent of urban deliveries.

* TBAs did not use a new blade for cutting the cord for 10 percent of rural deliveries and more than 26 percent of urban deliveries. Scissors and knives were sometimes used by TBAs.

* A new piece of thread was used for tying the cord for 89 percent of the deliveries.

Figure 4: Percentage of married women in DG Khan who made delivery arrangements, by type of arrangement

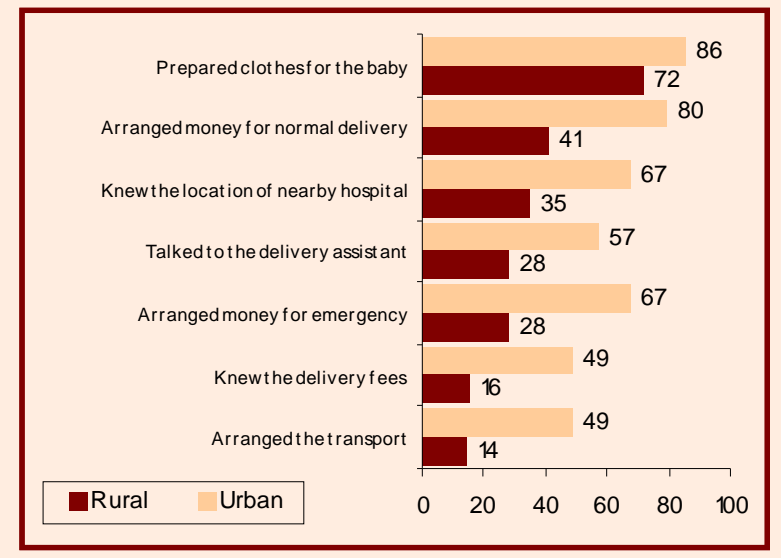

Figure 5: Percentage of births in DG Khan in the preceding three years, by place of delivery

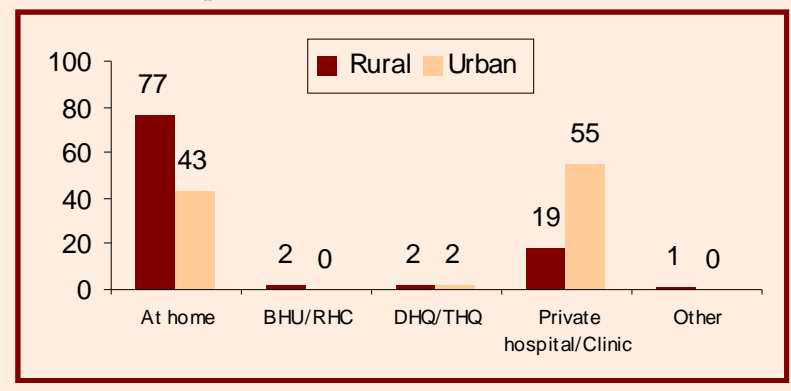

Figure 6: Percentage of births in DG Khan in the past three years, by type of last delivery

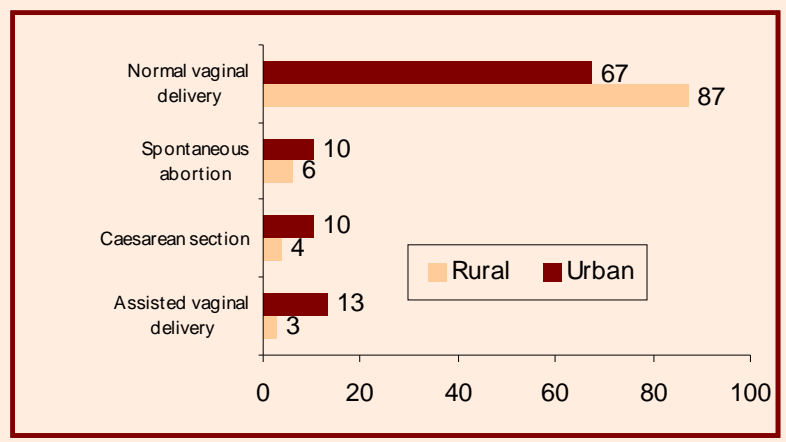




\section{Three Delays}

Delays in deciding to seek care, in reaching adequate health facilities, and in receiving appropriate care at health facilities lead to most maternal deaths.

\section{First delay: decisions must be made quickly}

* Women are often not prepared for delivery (figure-4) and don't know danger signs well (figure-1), and so are not well placed to make emergency decisions.

* The TBA is most likely (34 percent) to make the decision to seek emergency care, and probably has influence on family decisions as well. Getting them to make timely referrals is key.

\section{Second delay: transport must be at hand and available}

* Of those who seek treatment for delivery complication, 52 percent use own transport or private transport to reach the health facility. Forty-four percent call the service provider (usually the dai) to the home.

* The average waiting time for transport is 30 minutes.

* Transport averages 30 minutes to reach the desired facility, but in 7 percent of deliveries, it took more than one hour.

\section{Third delay: emergency services must be ready}

* After reaching the health facility, 96 percent report receiving services within 30 minutes. The median waiting time is 10 minutes.

- Appropriateness and quality of those services could not be ascertained.

\section{Access to media}

From figure 7, more than one-third in rural areas watch television, compared to three-quarters in urban areas. Few women listen to radio or read newspapers. About half of the population in Dera Ghazi Khan has access to some sort of media, whether it is television, radio or newspapers.

Figure 7: Percentage of married women in DG Khan who have access to mass media, by type of media

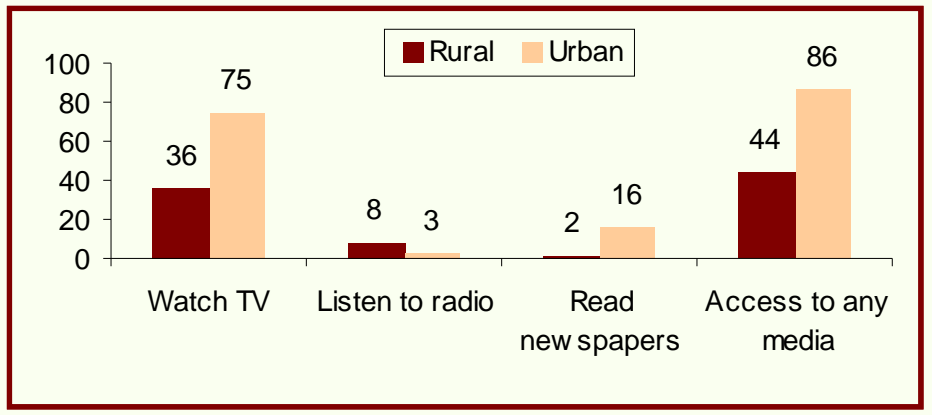

\section{Many pregnancies are unwanted}

* Twenty percent of respondents were using family planning at the time of the study. Female sterilization, withdrawal, and IUD are the most common methods. Thirty-eight percent of respondents expressed a desire to use family planning in the future.

* Forty-one percent reported that their last pregnancy was unwanted or mistimed. If unwanted pregnancies could be prevented in the first place, the attendant morbidity and mortality could be avoided.

\section{JSI}

JSI Research \& Training Institute, Inc.

CA \# 391-A-00-05-01037-00 project is funded by the United States Agency for International Development

and implemented by JSI Research \& Training Institute, inc. in conjunction with Aga Khan University, Contech International,

Greenstar Social Marketing, Johns Hopkins University/CCP, PAVHNA, The Population Council, and Save the Children USA 